\title{
SHAFTESBURY AS A POPPERIAN: CRITICAL RATIONALISM BEFORE ITS TIME? PART I
}

\author{
Keywords: humor, critical rationalism, Shaftesbury \\ Słowa kluczowe: humor, krytyczny racjonlizm, Shaftesbury
}

\section{Ridicule as the Test of Truth}

British philosopher of the Enlightenment, Anthony Ashley Cooper Shaftesbury is best remembered by both defenders and adversaries as the proponent of a doctrine compressed into the phrase "ridicule, the test of truth." This phrase never appears in exactly this form in the Characteristics, though Shaftesbury comes close to it in several places. There are four passages that are taken to refer to ridicule as the test of truth. The first passage associates reasoning with the test of ridicule: "How comes it to pass, then, that we appear such cowards in reasoning, and are so afraid to stand the test of ridicule?" (Letter, p. 2; CR I, p. 10). ${ }^{1}$ The second suggests that justified raillery is a principal proof

* Lydia Amir - College of Management Academic Studies, Rishon LeZion, Israel. Address for correspondence: E-mail: lydamir@colman.ac.il.

1 The references to Shaftesbury's works correspond to the following abbreviations: CR: Characteristics of Men, Manners, Opinions, Times, etc., ed. John M. Robertson, in two volumes, 1963; CR3: Characteristics of Men, Manners, Opinions, Times, etc., $6^{\text {th }}$ edition, corrected, in three volumes, 1737; Essay: Sensus Communis, an Essthe Freedom of Wit and Humour; Inquiry: Inquiry Concerning Virtue or Merit; Letter: Letter Concerning Enthusiasm; Life: The Life, Unpublished Letters, and Philosophical 
of truth: "Truth, 'tis supposed, may bear all lights; and one of those principal lights, or natural mediums by which things are to be viewed, in order to a thorough recognition, is ridicule itself, or that manner of proof by which we discern whatever is liable to just raillery in any subject" (Essay, i, p. 2; CR I, p. 44). The third substitutes wit and humor to ridicule: "Without wit and humour, reason can hardly have its proof or be distinguished" (Essay, i, p. 5; CR I, p. 52). Finally, the fourth passage suggests that humor and gravity test each other: "'Twas the saying of an ancient sage... that humour was the only test of gravity, and gravity of humour. For a subject which should not bear raillery was suspicious; and a jest which would not bear serious examination was certainly false wit" (Essay, i, p. 5; CR I, p. 52). A closer approximation to "ridicule, the test of truth" is found in some of the index entries Shaftesbury listed in the 1712 edition of the Characteristics:

Ridicule, its Rule, Measure, Test.

Test of Ridicule.

Truth bears all Lights. - Ridicule a Light, Criterion to Truth. (CR 3 III)

The controversy surrounding Shaftesbury's view of ridicule and its relation with truth along with the ensuing controversy over whether ridicule depends on reason or is an independent faculty have generated a heated debate in the $18^{\text {th }}$ century (see Aldridge, 1945). To this day, commentators are divided in their understanding of the meaning of Shaftesbury's views of ridicule. The majority of contemporary scholars, however, agree that the phrase "ridicule, the test of truth" does not adequately represent Shaftesbury's views because, they point out, he is advocating "the test of ridicule" and not a "test of truth." Moreover, Shaftesbury never implies that "Ridicule is the only infallible test of truth," as one of his contemporaries claims (Ibbott, 1727), nor does he ever contend, as another charges, that ridicule "may be successfully applied to the investigation of unknown Truth" (Brown, 1751, p. 6). For Shaftesbury, ridicule is not a means to discovering new truth, nor is it a logical proof of the truth or falsity of a proposition. It is doubtful that

Regimen of Anthony, Earl of Shaftesbury; Misc.: Miscellaneous Reflections on the Preceding Treatises, and other Critical Subjects; Moralists: The Moralists, a Philosophical Rhapsody; P.R.O.: The Shaftesbury Papers in the Public Record Office in at Kew, Surrey; Soliloquy: Soliloquy, or Advice to an Author. 
Shaftesbury ever thinks of ridicule as a mode of cognition. Ridicule is an instrument of reason, and it is reason ultimately which must distinguish between truth and falsehood.

One way of understanding "ridicule, the test of truth" is to take the phrase at face value and to assess it in light of Shaftesbury's theory of truth. Shaftesbury holds that reality is an organic, harmonious and perfectly congruous whole. Any statement that is true, or any statement that is descriptive of this reality, cannot but refer to these features, and while these characteristics may not give us a definition of truth, they do provide us with a criterion of truth. On the contrary, anything that lacks the characteristics of organic harmony and congruity is unreal. Any statement, therefore, that is incongruous, any statement that reveals an internal disharmony, is untrue. Falsehood is characterized by a quality that can only be described as ridiculous.

An assessment of Shaftesbury's view of ridicule requires further clarification of his conception of truth. Shaftesbury never doubts that a genuinely free interplay of ideas ensures that the best will prevail; only bad ideas suffer when subjected to free and humorous treatment (Essay, ii, p. 3; CR I, p. 65). Shaftesbury's defense of freedom of thought is based on the assumption that truth is more powerful than error (Letter, 1; CR I, p. 6). Falsity mimics truth, exists only as its parasite, and lies paradoxically reaffirm it. Thus, Shaftesbury is overwhelmingly confident that, where men are allowed free trial and experience, truth will prevail: "Let but the search go freely on, and the right measure of everything will soon be found" (Letter, 2; CR I, p. 10). In accordance with Shaftesbury's belief that free trade in goods is indicative of a healthy economy, free trade in ideas indicates a healthy culture. Free exchange of ideas is important for the religious sphere as well. True theism can only benefit from the establishment of an entire philosophical liberty (Life, p. 353), by which he means rational discussion in contradistinction to an appeal to emotions.

Shaftesbury's confidence in the power of truth to maintain its own in free discussion may seem optimistic, but it is not nad've. He recognizes that human beings may err as well as be misled by others, and that liberty can be abused, but he believes that generally extremes balance each other and are tempered by good manners; atheists in his own time, he notes, are using "modester and more polite" language (Life, p. 353). It is important to remember, finally, that his optimism about the predominance of truth is conditional on the degree to which human beings attain self-mastery and 
harmony of the affections, which are the prerequisites of sound reasoning and true freedom.

In a world where truth predominates and reason always benefits by free discussion, ridicule can pose no threat. In A Letter Concerning Enthusiasm Shaftesbury asks: "What ridicule can lie against reason?" (Letter, 2; CR I, p. 10). Indeed, he suggests that virtue has less to fear from its "witty antagonists" than from some of its ardent defenders. Yet, one cannot help asking, what about wit that is not "mannerly" and philosophy that is not "politely managed?" Shaftesbury's answer is twofold: the first is that humor should be controlled and regulated; the second is that truth is congruous and harmonious. Acknowledging the excesses to which wit may be carried, Shaftesbury's first answer insists primarily on the auto-regulation of humor

' $\mathrm{T}$ ' is in reality a serious study to learn to temper and regulate that humor which nature has given us as a more lenitive remedy against vice, and a kind of specific against superstition and melancholy delusion. There is a great difference between seeking how to raise a laugh from everything, and seeking in everything what justly may be laughed at. (Essay, iv, p. 1; CR I, p. 85)

There is a difference between "genteel wit" or "true raillery," on the one hand, and mere "buffoonery" or "banter," on the other. For Shaftesbury, the former is an instrument of reason; it presupposes self-control and the regulation of the passions. The latter form of laughter, "banter," is a passion, as are "extravagant mirth, airiness, humour, fantasticalness, buffoonery, drollery," whose control is as difficult as it is necessary and might come at the social cost of appearing uncouth (Life, p. 152-153). Moreover, laughter is "malignity hid under humanity" (Life, p. 160), that should be rejected since it runs counter to sympathy (Life, p. 225-226).

As with any other passion, laughter can be tamed by Stoic techniques of self-mastery. With sufficient practice, humor (hilaritas) can take the place of mockery (jocositas), as the goal of the soliloquy is to tame impotent laughter in order to make room for laughter as an instrument of reason. In addition to the private taming of laughter, Shaftesbury maintains that wit and humor tend to correct and refine themselves in company. "Freedom of wit," thus, is the best protection against false wit or "scurrilous buffoonery": 
[...] wit will mend upon our hands, and humour will refine itself, if we take care not to tamper with it, and bring it under constraint, by severe usage and rigorous prescriptions. All politeness is owing to liberty. We polish one another, and rub off our corners and rough sides by a sort of amicable collision. (Essay, i, p. 1; CR I, p. 46)

Even if wit exceeds its proper limits, which Shaftesbury concedes it may, an appeal to the magistrate for repression by force is not a good policy. If persons do not have the good sense to correct erroneous impressions in their own minds, governmental interference is not likely to help; rather it may make the situation worse, for political repression tends to encourage the "bantering" spirit.

While thought cannot be forcibly controlled, the public expression of opinion can and should be regulated to some degree. In public gatherings certain conventional limitations should be accepted willingly out of respect for common feeling and as a matter of good taste: "The lovers of mankind respect and honor conventions and societies of men" (Essay, i, p. 1; CR I, p. 46). In general, Shaftesbury's views on tolerance are in accord with those of John Locke and Matthew Tindal, whom he expressly praises. Thus, the liberty he defends amounts to "the liberty of the club," or the complete liberty of private conversation (Essay, i, p. 5; CR I, p. 53).

Shaftesbury's claim that humor should be both auto-regulated and refined through private conversation is his first response to those who criticize his view of ridicule as a test of truth. The second and more fundamental answer Shaftesbury offers is based upon the conviction that truth and virtue are ultimately congruous and harmonious, while error and vice are incongruous and inharmonious. Since the essence of the comic for Shaftesbury is incongruity and inconsistency, he sees error and vice as inherently ridiculous. On the other hand, truth and virtue do not lend themselves properly to comic treatment, as their mark is congruence and consistency:

Nothing is ridiculous except what is deformed; nor is anything proof against raillery except what is handsome and just... A man must be soundly ridiculous who, with all the wit imaginable, would go about to ridicule wisdom, or laugh at honesty, or good manners. (Essay, iv, p. 1; CR I, p. 85f)

Shaftesbury concedes that humor may be directed against good causes and against truth itself. He is willing to take this risk, however, because of 
his conviction that in a free society truth in the long run triumphs. Truth prevails because he believes true wit picks the right objects to ridicule while false wit does not.

The theory that ridicule is a test of truth may be seen as a logical development of Shaftesbury's optimistic philosophy. Philosophical optimism of the kind advocated in the Characteristics considers evil illusory. Much of what we regard as evil is not evil at all, according to this view, only part of a larger good; but in so far as evil does manifest itself, it conflicts with what is real. It can be laughed at as, strictly speaking, pure nonsense. Intrinsic evil is self-contradictory because ultimately it does not exist. Evil, which is tantamount to ugliness for Shaftesbury, is ridiculous, not only in the sense that it is capable of being ridiculed, but also in the sense that it is silly. This is the belief at the core of Shaftesbury's remarks on ridicule. One can safely laugh at evil, for good will always stands the test of ridicule, whereas evil will be seen in its true light as foolish. Thus, Shaftesbury maintains that "it is the hardest thing in the world to deny fair honesty the use of this weapon, which can never bear an edge against herself" (Essay, iv, p. 1; CR I, p. 85).

The idea that ridicule is a test of truth should be understood in light of Shaftesbury's theory of truth. Richard Brett emphasizes that the idea that ridicule is a test of truth is not something Shaftesbury thought out in passing. More than an aphorism, it is something he consistently maintains, firmly believes, and which, moreover, makes sense in relation to his view of truth as congruence and falsehood as incongruity (Brett, 1951, p. 171). The problem with this reading is that it makes the relation between ridicule and truth dependent on a view of truth that most of us may find difficult to endorse. Other readings, including those of Konrad Lorenz (Lorenz, 1966, p. 252-253), Ernst Cassirer (Cassirer, 1953, p. 183), Alfred Aldridge (Aldridge, 1945, p. 154), and Jean-Paul Larthomas (Larthomas, 1986, p. 359), translate Shaftesbury's doctrine of ridicule as the test of truth into a statement about insincerity: imposture and false gravity are what ridicule denounces. For Stanley Grean, however, the phrase "ridicule, the test of truth" denotes the free and objective state of mind with which we approach a subject and evaluate it (Grean, 1967, p. 123-124). Though all these assessments are correct - Shaftesbury did hold these views as well - I believe they do not capture the full import of Shaftesbury's assertion about ridicule. The above interpretations are not mutually exclusive, however. If 
ridicule is the test of truth for Shaftesbury, as I believe with Brett that it is, it follows that whatever cannot withstand free and humorous examination cannot be well-grounded in reason either, as Grean holds, and that ridicule's chief value may lie in its use as a test of demeanor to unmask imposture, as Lorenz, Aldridge, Cassirer and Larthomas maintain.

When attempting to assess the view that has become synonymous with Shaftesbury's name, that ridicule is the test of truth, one cannot avoid concluding that it is undeniably original, as no one before has ever proposed something similar. Yet this view makes sense mainly within the context of Shaftesbury's metaphysics and epistemology. Shaftesbury holds that reality is an organic, harmonious and perfectly congruous whole. Any statement that is descriptive of this reality cannot but refer to these features, and while these characteristics may not give us a definition of truth, they do provide us with a criterion of truth. On the contrary, anything that lacks the characteristics of organic harmony and congruity is unreal. Any statement, therefore, that is incongruous, any statement revealing an internal disharmony, is untrue. Falsehood is characterized by a quality that can only be described as ridiculous.

However, we cannot know that the world is an organic, harmonious and perfectly congruous whole without intuiting it through a capacity of the human soul that Shaftesbury names "enthusiasm." Shaftesbury's philosophy amounts thus to a religious faith through which we know the harmony of the world, the benevolence of God, and the goodness of human nature. Judged as a purely rational system that attempts to justify God's ways to humankind, Shaftesbury's philosophy fails. The evidence he presents can be matched by an equal amount of counterevidence. Stanley Grean suggests that much of what Shaftesbury thought clearly implied a designing Mind, we see today as a product of natural mechanisms of adjustment operating according to the patterns of statistical probability. Yet as a religious faith, his philosophy finally stands or falls to the extent that it makes "the tragic and the absurd endurable by including them in an ultimately meaningful universe" (Grean, 1967, p. 87-88). As a philosophy of life, it falls short for many in the contemporary world because, despite his realism, Shaftesbury's effort to see the necessity of all things prevents him from doing full justice to the inexplicably tragic dimensions of human experience.

Without taking into account Shaftesbury's metaphysics, the view that ridicule is the test of truth is controversial. The controversy over whether 
ridicule is a test of truth (whether ridicule is the proof of truth, or one of its tests, or not at all indicative of truth) and the ensuing controversy of its relation with reason (whether ridicule is a faculty that operates independently of reason or in conjunction with it) occupies an important place of concern for philosophers of the $18^{\text {th }}$ century. Never before has the relation between ridicule and truth been put on the agenda, or the definition of ridicule as a faculty been entertained; and never before has the way it works with reason been explored.

To maintain the view that ridicule is the test of truth, then, requires embracing the religious faith that Shaftesbury's metaphysics represents. This aspect of Shaftesbury's thought, though original, can be thus implemented only at a price that many may not be willing to pay.

\section{Humor and Good Humor as Habilitating Truth}

The relation of ridicule to truth - whether it is or is not the test of truth - does not exhaust Shaftesbury's views on the epistemological value of humor and good humor. Shaftesbury ascribes epistemological value to good humor as the attitude through which truth is most likely to be grasped. In maintaining that humor and good humor enable us to grasp the truth, he imparts to these notions a habilitating role.

For Shaftesbury life is neither tragedy nor comedy, thus neither gravity nor jest is the proper attitude towards it: it is rather a mixture of earnestness and jest. For want of a better term, Shaftesbury deems this mixture "another species of laughter," which he identifies sometimes as good humor and sometimes as humor (hilaritas). Good humor and humor are not clearly differentiated, but Shaftesbury occasionally suggests the latter is a means to the former. Humor is a remedy for the melancholy he diagnoses as the source of both a tragic view of life and certain forms of the comic, such as satire.

We know of humor's power against melancholy since antiquity as well as through the Renaissance school of medicine of Montpellier, where the French doctor Louis Joubert published treatises on the therapeutic value of humor $(1560$; 1578). Humor, Shaftesbury suggests, "is a kind of specific against superstition and melancholy delusion" (Essay, iv, p. 1; CR I, p. 85). Arising from the fear of chaos and arbitrariness in nature, melancholy yields disorders such as atheism, fanaticism or superstition - another form of depraved religion. By undermining melancholy or ill-humor, hu- 
mor helps in attaining the contrary disposition of character - good humor. Shaftesbury maintains that emotional states determine our outlook on life. Thus good humor acquires for Shaftesbury an epistemological value as the only disposition enabling us to perceive the truth about God, that $\mathrm{He}$ is benevolent; nature, that it is a perfectly congruent whole; human nature, that it is inherently good; and human beings, that to be harmonious, they should be virtuous.

Shaftesbury's argument for good humor can be found in the second miscellany section commenting on his defense of raillery in Sensus Communis:

$1^{\text {st. That }}$ wit and humor are corroborative of religion, and promotive of true faith.

$2^{\text {nd }}$. That they are used as proper means of this kind by the holy founders of religion.

$3^{\text {rd }}$. That notwithstanding the dark complexion and sour humour of some religious teachers, we may be justly said to have in the main a witty and good-humored religion. (Misc., II, p. iii; CR II, p. 217)

Shaftesbury's third point is the most substantive. The proposition is intended to praise concepts of divinity as beneficent, interpretations of Jesus as morally exemplary, and the ethic taught by Christianity as benevolent. Shaftesbury devotes considerable attention to the second point, maintaining that the chief "voices" in the Judeo-Christian tradition speak in a good humored way. He classifies as good humored writers the authors of the Old Testament, Jesus, the Apostles, and God (Misc., II, p. iii; CR II, p. 227-231). Christ's miracles "carry with them a certain festivity, alacrity, and good humour," and God's good-humored attitude toward Jonah, and even Satan, is for Shaftesbury a model to be emulated. Since the evidence of God's cheerful and good natured ways are everywhere, he concludes that we have "in the main a witty and good-humoured religion" (Misc., II, p. iii; CR II, p. 217, 229-231). Acknowledging religion as witty and good humored, as Shaftesbury proposes, would counter the sourness of enthusiastic intolerance: "All I contend for is to think of [religion] in the right humour... Good humour," he writes. Insofar as Shaftesbury's collected writings, the Characteristics, constitutes a "plea for complacency, sociableness, and good humour in religion," it seeks to submit religion to the discipline of politeness (Misc., II, p. iii; CR II, p. 224). 
Following the Stoics, Shaftesbury maintains that there is a correlation between the way we view reality and our attitude toward it. However, the vulgar attitude is not indicative of the true state of things: "The same rash opinion creates the evil as the good, where in reality there is neither... Why tragedy? Why a stage? Why witnesses?" (Life, p. 203). In contradistinction to the vulgar view of reality, he resolves that "no more of these parts to act, no tragedy. No comedy (mere comedy)" (Life, p. 193-194). Violent alternations from earnestness to jest should be particularly avoided (Life, p. 193). He portrays accordingly his ideal as a "middle genius, partaking neither of hearty mirth nor seriousness" (Life, p. 194-195). Elsewhere he maintains that "a mirth not out of the reach of wit is gravest. A gravity not abhorrent from the use of that other mirth. In this balance seek a character" (Life, p. 362). The mixture of "jest" and "earnest" that Shaftesbury calls "soft irony" characterizes the social self at its best, that is, a social self that corresponds with the philosophical self: "Such a tenour as this, such a key, tone, voice, [is] constituent with true gravity and simplicity, though accompanied with humor and a mind of raillery" (Life, p. 362-366). While the Shaftesburean ideal self maintains gravity and simplicity, it mitigates seriousness with humor and raillery in a "sober kind of cheerfulness" (Letter, p. 2-3; CR I, p. 17).

Both in the Exercises (Askemata), a posthumously published part of his notebooks, which describes his philosophic regimen, and in an unpublished text in Latin, "Pathologia sive Explicatio Affectum Humanorum," Shaftesbury portrays his ideal by differentiating between hearty laughter and a gentler kind of laughter. In the Exercises, he writes: "How happy would it be, therefore, to exchange this vulgar, sordid, profuse, horrid laughter for that more reserved, gentle kind, which hardly is to be called laughter, or which at least is of another species?" (Life, p. 226). He advises himself to use this kind of laughter only, modeled on "that divine facetiousness (if so I may call it) of the divine man [Epictetus]" (Life, p. 82), and on the laughter of Socrates and his follower Xenophon, the playwright of the new comedy Menander, and also the cynics Demonax and Diogenes, because cynicism was praised by Epictetus. This philosophic laughter Shaftesbury calls good humor, or simply humor - the term by which we know it today.

A telling description of Shaftesbury's favored kind of laughter can be found in the unpublished Latin text that antedates A Letter on Enthusiasm - "Pathologia sive Explicatio Affectum Humanorum." Shaftesbury's trea- 
tise finishes with a long discussion on the nature of laughter, whose end he reiterates in A Letter on Enthusiasm. As his later prose in English tends to avoid the pedagogic style that characterizes "Pathologia," nothing he subsequently writes on the subject of laughter is as precise as its description in "Pathologia." In this work Shaftesbury distinguishes between two different kinds of laughter,jocositas or mockery, which is a form of evil, and hilaritas, the Latin term for humor, which is a form of admiration:

For hilaritas ("humour") and jocositas ("mockery") are not the same thing. Indeed, hilaritas, this sort of moderate laughter which can be mastered is a form of admiration, a certain joy which is born of the spectacle or the examining of an exterior object that we judge beautiful. For if we consider this object as pertaining to ourselves, either naturally or at the end of the effort which allowed us to make it ours, immediately such joy deteriorates into boastfulness or pride, if it is about very high qualities. Jocositas is a sort of hearty laughter, which does not let itself be managed, for it is the joy that a shameful hideousness in another causes us, which is foreign to us but as if it represented a good for us. Pleasure and joy can come from a good and beautiful object, either such or one which we take it for such. Since such a laughter is no desire nor aversion nor pain, but pleasure and joy, it follows necessarily that its object, that is, this ridicule or this evil, is held as good and beautiful from our point of view. It is therefore from malevolence and hatred that this laughter stems, it is therefore a species of evil (malevolence), a pleasure derived from the misfortune of another. (P.R.O 30/24/26/7, I, my translation)

The remainder of the text makes Shaftesbury's case clear - because jocositas or hearty laughter cannot be tamed, it must be eradicated. As Shaftesbury explains in his notebooks, until this kind of laughter is completely eliminated, laughter cannot be controlled. Only when hearty laughter has entirely vanished, can the other kind of laughter - "this sort of moderate laughter which can be mastered" - be used without fear of losing control. The second kind of laughter, hilaritas, derives from admiration and laughs with beauty rather than at ugliness. Admiration should be directed only outwards, for when directed inwards it turns into pride or boastfulness. As in the Exercises, Shaftesbury calls hilaritas good humor or simply humor.

Through his notion of humor, Shaftesbury revives an ancient philosophic ideal that furthers the $18^{\text {th }}$ century view of humor as amiable. The 
notion of amiable humor is promoted by, and in turn helps to promote, close interrelations between jest, on the one hand, and earnestness, tragedy, tears, melancholy, sympathy and pathos, on the other. The ideal of amiable humor underlies Shaftesbury's disapproval of other forms of the comic whose aim is not moral criticism and also presupposes the taming of any other kind of laughter.

In assessing whether good humor is epistemologically valuable, it is important to remember that, for Shaftesbury, it acquires an epistemological value as the only disposition that enables the perception of the truth about God, nature, human nature, and virtue. Shaftesbury means by truth, first, the right view of God, the world, and human nature, which for him are God's benevolence, nature's harmony, and innate human goodness. Good humor as the pre-disposition to gaiety is a necessary condition for understanding goodness: "We must not only be in ordinary good-humour, but in the best of humours, and in the sweetness, kindest disposition of our lives, to understand well what true goodness is..." (Letter, p. iv; CR I, p. 24-25).

Ascribing an epistemological value to good humor is entirely original; yet, strictu sensu, good humor promotes truth if the world is indeed good and harmonious. If the world is not such a place, Shaftesbury's recommendation of good humor is prudential advice, based on his view that emotional states determine our outlook on life. However, good humor has a habilitating function with regard to truth in another sense as well. Through pleasant, free and well-intentioned conversation, good humor provides the openness necessary for the pursuit of truth. It is through conversation that the truth of human matters is pursued, if not reached, and there is no conversation without social pleasure. Good humor establishes an atmosphere of tolerance that invites the other's opinion. This view of good humor, which is fairly independent of epistemological assumptions, is as viable today as it was in Shaftesbury's epoch.

If good humor has a habilitating function with regard to truth, it remains to be seen whether humor also promotes truth. The answer is hindered by the fact that in Shaftesbury's writings humor is not clearly differentiated from either good humor or ridicule. In the unpublished "Pathologia," for example, Shaftesbury portrays a new kind of laughter, hilaritas, or humor, which delights in the beautiful rather than in the ugly. This form of humor is not easily differentiated from good humor. Nevertheless, an assessment of its value and originality is in order. 
If we take hilaritas to mean good-natured humor, I do not know how much Shaftesbury should be credited for innovating on this subject. There are important antecedents to Shaftesbury's hilaritas, and he appeared to have been familiar with a number of them. In contradistinction to the accepted view, as stated, for example, by Max Eastman in The Sense of Humor (Eastman, 1972 [1922], p. 167), Louis Cazamien and others maintain that the discovery of benign (or non-aggressive) humor is not an $18^{\text {th }}$ century phenomenon (Cazamien, 1952; Haury, 1955; Grant, 1924, p. 148). Ancient Greek and Hellenistic philosophers differentiated between kinds of laughter and favored the mild and good-natured laughter, as exemplified by Xenophon, Aristotle, Cicero, and the Stoics' preferred choice of irony or humor.

Socratic irony, as understood by Xenophon, is Shaftesbury's ultimate model in the Exercises, but Aristotle also serves as a model for good-natured laughter. The Aristotelian virtue of eutrapelia, the social virtue of cheerfulness, or wit, is the antecedent of Shaftesbury's notion of good humor. Employing his usual tripartite division, Aristotle maintains in the Nicomachean Ethics that the excess of laughter is buffoonery and its deficiency is boorishness. Nonetheless, there exists a "true wittiness" characteristic of an honorable and free person (Aristotle, Nicomachean Ethics, 4.8. 1127b ff; see Rhetoric, 2.12, 1389, p. 11-12). The ready-witted (eutrapelos), being a tactful person, does not utter injurious or offensive comments, whereas the buffoon says and does anything in order to raise a laugh. Only the ready-witted, being a refined person, can decide what is appropriate and what is inappropriate regarding laughter and what is suitable for a free man to say and hear.

Aristotle's view of humor is reprised by Cicero, who clearly shows a theoretical preference for good-natured humor: his "hilaritas" as well as "festivitas" imply a kindly spirit of jesting (Grant, 1924, p. 107). It is the Stoic Panaetius (c. 185-109 B.C.), however, whose views are best preserved in the adaptation of his work On the appropriate by Cicero in the latter's De Officiis, and who incorporates Aristotle's views into Stoicism to make the school palatable to the Romans. Panaetius takes virtue to be a mean between two vices, and this doctrine, alien to true Stoic principles, forms the basis of the treatment of laughter in Cicero's De Officiis. Moreover, Socrates becomes for Panaetius the ideal embodiment of Aristotle's eutrapolos, or Cicero's liberal joker (his coining for Aristotle's free man). This kind of humor Panaetius found to be the most appropriate for the plain style his 
teacher Diogenes of Babylon developed. Panaetius assailed the aesthetic and moral coarseness of Cynic speech with its coarse and frank humor as a sin against social propriety, favoring instead Aristotle's definition of the liberal jest.

George Converse Fiske traces the development of the theory of diction and humor appropriate to the sermo or conversational discourse in plain style - the type of oral and written expression favored by the truth-loving Stoics - formulated for the Romans by Diogenes of Babylon and Panaetius, and employed as a result of their influence in nearly all the literature emanating from the Scipionic circle. This was a society of the noblest and most intelligent men of Rome that gathered around Scipio Aemilianus and his Greek friends, the historian Polybius and the philosopher Panaetius (Fiske, 1920, p. 17; 1919). Fiske maintains that the Socratic theory of irony-the type of liberal humor pervading the conversations of Socrates and the Platonic dialogues - that was widely prevalent in the Scipionic circle accords with the rhetorical theory appropriate to the conversational discourse in plain style. We know that through Roman philosophers, the Hellenistic schools of philosophy influenced later generations in the Renaissance, Early Modern times and the Enlightenment, and we also know that Shaftesbury was steeped in Roman philosophy. Thus, if we take Shaftesbury's hilaritas to mean good-natured humor, we cannot credit him with much originality.

However, the good humor of hilaritas stems from the admiration of (external) beauty. There are no views of laughter in ancient philosophy that come close to Shaftesbury's admiration for beauty. Nevertheless, the seventeenth-century philosopher Baruch Spinoza, an important forerunner of Shaftesbury (Robertson, 1963, p. xxxi), uses hilaritas to define a new form of laughter, which has been translated into English as "cheerfulness" or gaiety (Ethics, III, P11Schol.). According to Spinoza, cheerfulness cannot be excessive and is always good while its opposite, melancholy, is always evil (Ethics, IV, P42, and Dem.; P44Schol.). Spinoza differentiates in most of his writings between scorn or mockery, which he rejects, and laughter, which he embraces. In the Political Treatise, he warns us not to scorn or mock, urging us, rather, to understand humankind (Political Treatise, I, 4). In the Ethics, mockery is defined as a form of hatred, and thus a kind of sadness, which can never be converted into joy. Laughter and joking, when not excessive, in contrast, are characterized as pure joy, partaking thus in Spinoza's pantheistic God-Nature (Ethics, IV, P45 Cor. 2, and Schol.). Similarly, in the 
Short Treatise on God, Man, and his Well-Being, he differentiates between mockery and ridicule, on the one hand, and laughter, on the other: "Mockery and ridicule rest on a false opinion and indicate an imperfection in he who mocks and ridicules," he writes. "They indicate an imperfection in him who mocks because either what is mocked is ridiculous or it is not." If it is not, it should not be mocked. If it is, it should be amended by other means than mockery. In contradistinction, "laughter is not related to another, but only to the man that notices something good in himself; and because it is a kind of joy, there is nothing to say about it which has not already been said about joy," that is, it is always good (Short Treatise, II, chap. XI, p. 115-116).

Spinoza's hilaritas or cheerfulness may be an antecedent to Shaftesbury's good humor. Editor John Robertson has maintained that Shaftesbury's philosophy is none other than Spinoza's (Robertson, 1963, p. xxxi). However, there are important differences between the hilaritas of each philosopher. While for Shaftesbury the source of hilaritas is always external, an admiration of external beauty and never of oneself, the source of Spinoza's hilaritas is internal, a delight in oneself. It is Spinoza that innovates radically. Shaftesbury's hilaritas innovates in the admiration of beauty it involves, given that Shaftesbury has adopted the ancient philosophers' association of ridicule with ugliness or disharmony, but Shaftesbury limits the range of hilaritas by excluding one's character from being a source of admiration.

Although Shaftesbury's view of humor has antecedents in ancient philosophical views of good-natured laughter, the concept of hilaritas, albeit not entirely new when compared with a similar concept in Spinoza's philosophy, innovates in proposing a cheerfulness that stems from the admiration of beauty. There are no views of laughter in ancient philosophy that come close to Shaftesbury's admiration for beauty. Hilaritas or cheerfulness can be adopted today independently of any metaphysical explanation or justification of the beauty perceived.

It will be continued in no. 36

\section{References}

Blanshard, B. (1980). Selections from On Philosophical Style. In: Philosophical Style (p. 123-143). Berel Lang. 
Cassirer, E. (1953). The Platonic Renaissance in England. Trans. J.P. Pettegrove. Edinburgh: Thomas Nelson and Sons.

Cazamien, M.L. (1952). The Development of English Humor. Trans. R. Guyonnet. Durham: Duke University Press.

Hark, M. ter. (2004a). Popper, Otto Selz, and the Rise of Evolutionary Epistemology. Cambridge: Cambridge University Press.

Hark, M. ter (2004b). The Psychology of Thinking, Animal Psychology, and the Young Karl Popper. Journal of the History of the Behavioral Sciences, 40 (4), 375-393.

Horace (1959). The Satires and Epistles of Horace. Chicago, IL: University of Chicago Press.

Keut, H. (2005). The Philosophy of Karl Popper. Cambridge: Cambridge University Press.

Klein, L.E. (1994). Shaftesbury and the Culture of Politics. Cambridge: Cambridge University Press.

Larthomas, J.-P. (1986). Humour et enthusiasme chez Lord Shaftesbury (1671-1713). Archives de philosophie, 49, 355-373.

Popper, K.R. (1927). “Gewohnheit” und “Gesetzerlebnis”. In: Der Erziehung: Eine pädagogisch-strukturpsychologische Monographie. Hoover Institute Archives. Karl Popper Papers, box 12, file 11.

Popper, K.R. (1959). The Logic of Scientific Discovery. London: Hutchins.

Popper, K.R. (1961). The Poverty of Historicism. London: Routledge and Kegan Paul.

Popper, K.R. (1962). The Open Society and Its Enemies. 2 vols. London: Routledge and Kegan Paul.

Popper, K.R. (1963). Conjectures and Refutations: The Growth of Scientific Knowledge. London: Routledge and Kegan Paul [ $5^{\text {th }}$ revised edition, 1989].

Popper, K.R. (1974). Intellectual Autobiography. In: The Philosophy of Karl Popper (The Library of Living Philosophers, vol. 15), Books I and II, Paul A. Schilpp (ed.). Vol. 2 (p. 961-1197). La Salle, IL: Open Court.

Popper, K.R. (1994). The Myth of the Framework. London: Routledge.

Shaftesbury, A.A.C. (1963 [1900]). Characteristics of Men, Manners, Opinions, Times, etc., Gloucerster, MA: Peter Smith. 
Shaftesbury, A.A.C. (1837). Characteristics of Men, Manners, Opinions, Times, etc., $6^{\text {th }}$ edition, 3 vols, corrected. London: James Purser.

Shaftesbury, A.A.C. (1992 [1900]). The Life, Unpublished Letters, and Philosophical Regimen of Anthony, Earl of Shaftesbury, London: Swan Sonnenschein and New York: Macmillan.

Shaftesbury, A.A.C. (1698-1712). Askêmata, two notebooks. The Shaftesbury Papers in the Public Record Office in London (P.R.O.) 30/24/27/10.

Shaftesbury, A.A.C. (1706). Pathologia sive Explicatio Affectum Humanorum. The Shaftesbury Papers in the Public Record Office in London (P.R.O.) 30/24/26/7.

Smith, H. (2001). The Meaning of Life in the World's Religions. In: J. Runzo, N. Martin (eds.), The Meaning of Life in the World Religions (p. 255-268). Oxford: Oneworld.

\section{SHAFTESBURY AS A POPPERIAN: CRITICAL RATIONALISM BEFORE ITS TIME? PART I}

\section{Summary}

Shaftesbury has assigned humor an unparalleled role within philosophy, which may be encapsulated in the following tenets: (1) ridicule is the test of truth; (2) humor and good humor have a habilitating function with regard to truth; (3) the most effective criticism is humorous; and (4) humor is the mark of rationality. In the present article, I introduce Shaftesbury's views on ridicule, good humor and humor in order to assess both the originality and viability of Shaftesbury's contribution. I argue, first, that Shaftesbury's views on ridicule as a test of truth and on good-humor as habilitating truth are thoroughly original, but cannot be implemented without adhering to his metaphysics and epistemology. Second, Shaftesbury's views on humor are only partially original, though these can be implemented independently of metaphysical and epistemological assumptions for the greatest benefit of philosophers in general and critical rationalists in particular. I conclude that not only does Shaftesbury anticipate the view that critical thinking is the core of rationality, the main principle of the view known as critical rationalism associated with the renown $20^{\text {th }}$ century philosopher of science and social philosopher, Karl Popper, but he also offers a viable means to enhance criticism as rationality by taking into consideration the psychological resistance to criticism that Popper acknowledges but refuses to address. 